Utah State University

DigitalCommons@USU

CWEL Publications

2009

\title{
A survey of apomixis and ploidy levels among Poa L. (Poaceae) using flow cytometry
}

\author{
Alicia Michelle Kelley \\ Paul G. Johnson \\ Utah State University \\ Blair L. Waldron \\ Michael D. Peel
}

Follow this and additional works at: https://digitalcommons.usu.edu/cwel_pubs

Part of the Plant Sciences Commons

\section{Recommended Citation}

Kelley, Alicia Michelle; Johnson, Paul G.; Waldron, Blair L.; and Peel, Michael D., "A survey of apomixis and ploidy levels among Poa L. (Poaceae) using flow cytometry" (2009). CWEL Publications. Paper 38.

https://digitalcommons.usu.edu/cwel_pubs/38

This Article is brought to you for free and open access by DigitalCommons@USU. It has been accepted for inclusion in CWEL Publications by an authorized administrator of DigitalCommons@USU. For more information, please contact digitalcommons@usu.edu.

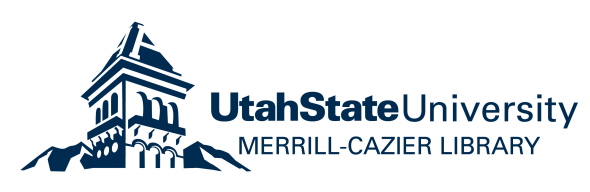




\title{
A Survey of Apomixis and Ploidy Levels among Poa L. (Poaceae) Using Flow Cytometry
}

\author{
Alicia Michelle Kelley, Paul G. Johnson,^ Blair L. Waldron, and Michael D. Peel
}

\begin{abstract}
Poa is a complex genus taxonomically and genetically. As a result, relatively little information exists for this economically important genus with regards to reproductive mode and variability in chromosome number. We examined apomixis frequency and ploidy levels in 83 Poa accessions representing 33 species from the National Plant Germplasm System using flow cytometric techniques. In reproductive mode analysis, we analyzed at least three preparations of 50 seeds each from the accessions. In ploidy level analysis, at least three plants of each accession were analyzed. Sixty percent of the species had at least one apomictic or facultative apomictic accession; $40 \%$ were sexual. Thirty-three percent of the species had no sexual accessions. Autonomous apomixis was newly identified in $P$. bactriana and $P$. bulbosa in addition to it being previously reported in $P$. nervosa. Poa annua and $P$. trivialis were identified as obligate sexual, and $P$. nervosa as obligate apomictic. Two of four $P$. palustris accessions exhibited facultative apomixis. Ploidy levels among sexually reproducing Poa accessions ranged from $2 n=2 x=14$ to $2 n=12 x=84$, with most accessions between $2 n=3 x=21$ to $2 n=8 x=56$. Among apomictic accessions, ploidy levels ranged from $2 n=3 x=21$ to $2 n=10 x=70$, with most between $2 n=4 x=28$ and $2 n=10 x=70$. These results emphasize the wide variability in Poa, both among and within species.
\end{abstract}

A.M. Kelley, Seattle, WA; P.G. Johnson, Dep. of Plants, Soils, and Climate, Utah State Univ., 4820 Old Main Hill, Logan, UT 84322-4820; B.L. Waldron and M.D. Peel, USDA-ARS, Forage and Range Research Lab., 690 North 1100 East, Logan, UT 84322-6300. Received 22 Sept. 2008. *Corresponding author (paul.johnson@usu.edu).

Abbreviations: NPGS, National Plant Germplasm System.

DA, commonly known as bluegrass, includes over 500 species (Gillespie and Soreng, 2005) of which 69 are present in the United States (Balasko et al., 1995) and at least 40 of those have agronomic importance (Hovin, 1980). Among the most widely cultivated is Poa pratensis, (Kentucky bluegrass), which is known in many temperate regions of the world because of its rapid colonization and high-quality turfgrass characteristics, forage quality, and erosion control (Balasko et al., 1995; Weddin and Huff, 1996; Huff, 2003). Poa pratensis is a facultative apomict that is highly variable in chromosome number. Both of these genetic characteristics appear to enable its wide adaptation and genetic diversity (Bashaw and Funk, 1987). The same statement can be made for many other Poa species as well (Gillespie and Soreng, 2005); however, both apomixis and ploidy level variation present challenges in genetic improvement of Poa.

To improve stress tolerance traits of $P$. pratensis for turfgrass and other agronomic uses, interspecific hybridization with other Poa species has been a goal of many plant breeders. An example of a commercially successful hybrid is between $P$. pratensis and $P$. arachnifera (Abraham et al., 2004). However, a high level of apomixis has generally limited traditional breeding success. Identification of sexually reproducing lines is necessary to select the most productive interspecific breeding candidates. In addition, species

Published in Crop Sci. 49:1395-1402 (2009).

doi: 10.2135/cropsci2008.09.0553

(C) Crop Science Society of America

677 S. Segoe Rd., Madison, WI 53711 USA

All rights reserved. No part of this periodical may be reproduced or transmitted in any form or by any means, electronic or mechanical, including photocopying, recording, or any information storage and retrieval system, without permission in writing from the publisher. Permission for printing and for reprinting the material contained herein has been obtained by the publisher. 
with similar ploidy levels usually improve hybridization and can also be an important factor in determining interspecific compatibility.

Apomixis frequency can vary considerably in the genus Poa, even within a single species. Apomictic clones in P. pratensis can vary between 25 and 96\% apomictic (Huff, 2003). Outside of $P$. pratensis, ploidy levels and apomixis information exists for just a few of the Poa species (Kellogg, 1987; Soreng, 2000). Little or no information is available on the USDA National Plant Germplasm System (NPGS) entries of Poa, other than some P. pratensis entries (Wieners et al., 2006).

Traditionally, reproductive mode of plants is evaluated using cytological techniques. Immature ovaries (pistils) are dissected to view developmental progress of the megagametophyte. This process requires precise morphological stage harvesting and is time intensive. Therefore, these methods are typically not feasible for a large survey of species. Progeny testing and comparisons of morphology with the maternal plant can also estimate reproductive modes. This again is time consuming, requires a large amount of space, and is only as accurate as morphological traits allow. To address these challenges, Matzk et al. (2000) described a technique using flow cytometry to evaluate levels of apomixis. The process uses mature seeds and measures the difference in DNA contents among embryo and endosperm cells. Depending whether the seed was produced through apomixis or sexual reproduction, the varying DNA contents can be detected using flow cytometry. This method has been used effectively for P. pratensis (Wieners et al., 2006).

Determination of ploidy levels in Poa can be made by conducting chromosome counts of root tip cells, also a very time consuming process, especially for Poa, which often has small chromosomes in high numbers. Alternatively, ploidy level has routinely been evaluated using flow cytometry as an indirect method of making chromosome counts. Flow cytometry measures DNA content of somatic cells, which is used to infer chromosome number and ploidy level (Arumuganathan and Earle, 1991). This method has been used effectively in many species including $P$. pratensis (Wieners et al., 2006) and, similar to estimates of reproductive mode, enables an accurate method to evaluate ploidy level in a large number of individual plants. However, chromosome counts would be needed if confirmation of ploidy level is required.

Breeding advances in Poa, especially if interspecific hybridization is used, will benefit from more knowledge of ploidy levels and reproductive mode in species and lines. To address this need, we examined apomixis frequency and estimated ploidy levels in a collection of Poa species. Our specific objectives were (i) to determine the extent of apoximis in 33 different Poa species from the NPGS and (ii) to estimate ploidy levels from the same Poa accessions. To study a large number of accessions, the objectives will be addressed using flow cytometric techniques.

\section{MATERIALS AND METHODS Reproductive Mode Analysis}

Eighty-three Poa accessions representing 33 species were obtained from the NPGS (USDA-NRCS, 2008). Several accessions of the same species were obtained from different collection sites to identify reproductive variation within a species. Most of the accessions were chosen in part because they were from arid regions. Several of the same species were obtained from different collection sites to estimate variation within a species.

Reproductive mode was analyzed using methods similar to those described by Matzk et al. (2000). Approximately 50 seeds of each accession were finely chopped with a razor blade for $5 \mathrm{~min}$ in $0.4 \mathrm{~mL}$ DAPI UV Precise P Nuclei extraction buffer using the Partec CyStain kit (Partec GmbH, Görlitz, Germany). The solution was filtered $(50 \mu \mathrm{m})$ and $1.6 \mathrm{~mL}$ of staining buffer was added to the supernatant. Samples were stored on ice for $2 \mathrm{~min}$ before flow cytometry analysis. Cells were analyzed using a Partec PA-II flow cytometer with the HBO (ultraviolet light source) lamp (Partec GmbH, Görlitz, Germany). The flow cytometer output was a histogram created from counts of fluorescence intensity of stained DNA in each cell. Peaks on the histogram represented nuclei from cells within the seeds and were used to evaluate the reproductive mode pathway as described below. Three separate preparations (repetitions) of each accession were analyzed. Ratios between the peak means were then calculated to determine relative amount of DNA in each type of cell.

In a sexually produced seed, the largest peak in the flow cytometer histogram output correlated to the $2 \mathrm{C}$ embryo, where $\mathrm{C}$ refers to the amount of DNA in an unreplicated haploid nuclei. This means a 2C DNA content is the DNA in an unreplicated genome. A second peak, with 1.5 times more fluorescence, represented the $3 \mathrm{C}$ endosperm cells formed during double fertilization (Fig. 1). The presence of these two peaks and the ratio of their intensity (location along the $x$ axis of the histogram) indicated whether the seeds were produced through sexual reproduction (Matzk et al., 2000). Seeds produced by pseudogamous apomixis resulted in a $2 \mathrm{C}$ embryo peak and a $5 \mathrm{C}$ endosperm peak (Fig. 2). The 5C endosperm is created from the fusion of two unreduced polar cells with a haploid sperm nucleus. Other peaks that may form through other reproductive methods, similar to that described by Wieners et al. (2006), include (i) autonomous apomicts - a 2C embryo and a 4C endosperm formed due to the omission of fertilization; (ii) apomicts with a reduced unfertilized embryo (1C) and a fertilized reduced endosperm (3C); and (iii) unreduced and fertilized embryo (3C) and a fertilized unreduced endosperm (5C). Since the method we used involved the preparation of many seeds from possibly more than one individual plant, a combination of these reproductive modes was often observed. For example, analysis of a facultative 
apomict would have a histogram output with $2 \mathrm{C}, 3 \mathrm{C}$, and $5 \mathrm{C}$ peaks (Fig. 3).

\section{Ploidy Level Analysis}

Ploidy levels of the various Poa accessions were estimated using flow cytometry (Doležel and Bartoš, 2005) by comparing the relative DNA content of the Poa accessions to $P$. annua L., a known tetraploid. Our methods used 4',6-diamidino-2-phenylindole (DAPI) staining. The $P$. апnиa clone used for comparison was confirmed as a tetraploid $(2 n=4 x=28)$ through chromosome counts on root tip cells.

Leaves from three individual plants of each accession were sampled, prepared, and analyzed separately. For each preparation, fresh leaf tissue (approximately $0.25 \mathrm{mg}$ ) was obtained from young leaves of the Poa species accession and an equal amount from the $P$. annua standard. The combined leaf tissue was finely chopped for 30 to $90 \mathrm{~s}$ with a sharp razor blade in $0.5 \mathrm{~mL}$ of CyStain UV Ploidy Solution (Partec GmbH, Görlitz, Germany). Another $1.5 \mathrm{~mL}$ of CyStain UV Ploidy Solution was added, and after incubation for 4 to 5 min at room temperature, the solution was filtered $(50 \mu \mathrm{m})$. Each sample was analyzed on a Partec PA II Flow Cytometer using the HBO lamp to a minimum of 5000 nuclei count. To be certain of the origin for the two histogram peaks, additional samples were run of both the unknown Poa and $P$. annua separately. Ploidy levels were then determined from the ratio of the $P$. annua and unknown peaks using the following equation: mean peak value for the unknown Poa species divided by the mean peak level for the $P$. annua standard multiplied by 4 (the ploidy of $P$. annua).

The flow cytometry procedure was done under the assumption that the Poa species had similar chromosome size. We acknowledge that this may be a generous assumption in some cases and limits the precision of the results. However, this method does give a general and relative estimate of ploidy for those accessions, which was a first recording for many of these species.

\section{RESULTS AND DISCUSSION Mode of Reproduction}

Overall, 60\% of the Poa species evaluated had at least one apomictic or facultative apomictic accession. The remaining $40 \%$ displayed only sexual reproduction. Thirty-three percent of the apomictic accessions displayed obligate apomixis, as represented by only $2 \mathrm{C}$ and $5 \mathrm{C}$ peaks in the flow cytometer output (Table 1). Poa nervosa is one of the few autonomous

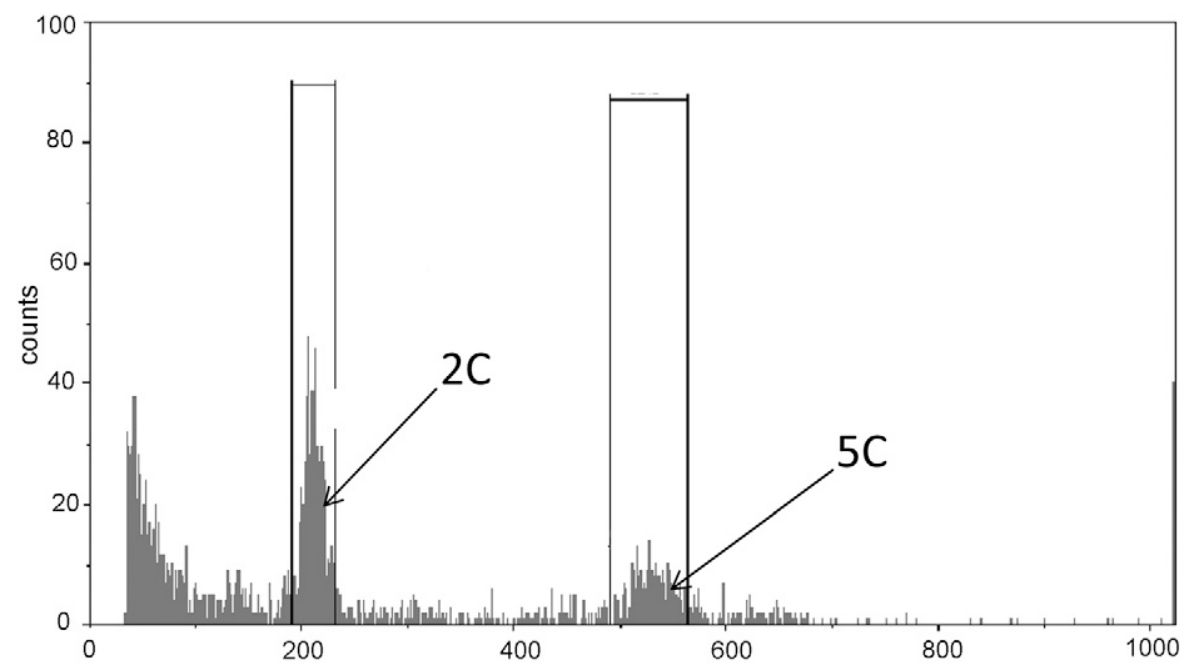

Figure 2. Histogram from a flow cytometer output of an obligate apomictic species of Poa displaying a larger 2C embryo peak with a 5C endosperm peak. apomict species reported in the literature (Grun, 1955). Our results were confirmatory but also found $P$. bactriana and $P$. bulbosa to be autonomous apomicts as each accession within these species displayed only $2 \mathrm{C}$ and $4 \mathrm{C}$ peaks (Table 1 ).

A 6C peak was detected in seed samples of $P$. nemoralis (PI 206728) (Table 1). Since a 3C peak was not detected, the 6C peak was not formed due to the presence of mitotic cells. Because $P$. nemoralis is highly apomictic, the $6 \mathrm{C}$ peak may be endosperm cells created from the fusion of two unreduced polar nuclei and an unreduced pollen cell. Dissection of the ovule during formation would be required to confirm this.

Results from two of six P. secunda accessions (PI 232347 and PI 504370) indicated $1 \mathrm{C}$ and 3C peaks (Table 1). This result points to a reduced but apomictic embryo with fertilized endosperm. This same result was also observed in P. pratensis accession by Wieners et al. (2006).

Many Poa species had reproductive modes that corroborate previously published results (Table 1); our data support $P$. annua and $P$. trivialis as obligate sexual and $P$. nervosa as 


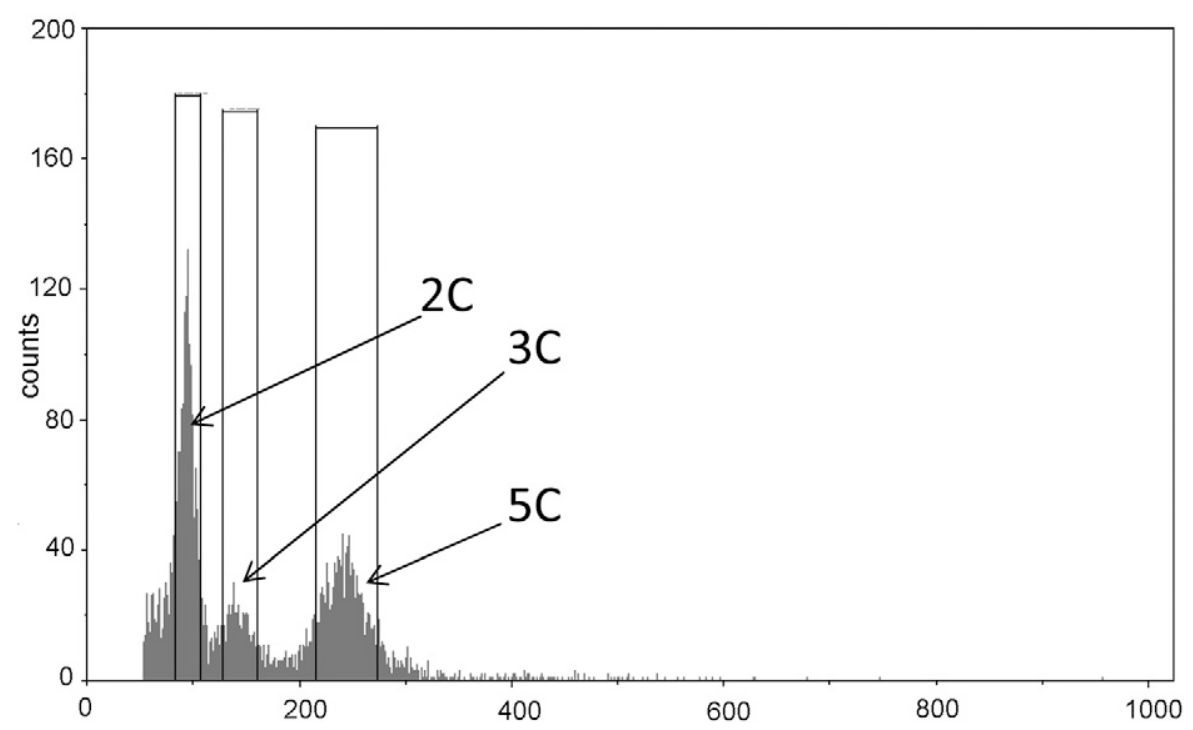

Figure 3. Histogram from a flow cytometer output of a facultative apomictic species of Poa displaying a 2C embryo peak with a $3 \mathrm{C}$ and $5 \mathrm{C}$ endosperm peaks, suggesting a mix of apomictic and sexually produced seeds.

an obligate apomictic species. However, P. palustris has been reported to be an obligate apomict, but in our study two of the four $P$. palustris accessions displayed facultative apomixis. These accessions had flow cytometry outputs indicating seeds with $2 \mathrm{C}$ embryos with $3 \mathrm{C}$ and/or $5 \mathrm{C}$ endosperm (Table 1). In other apomictic species, not belonging to Poa, there is evidence for apomictic individuals that display a $2 \mathrm{C}$ and 3C peak (Asker and Jerling, 1992). It is also possible that the 3C peaks were formed through an unreduced embryo and an unreduced and fertilized endosperm. However, neither of these have been observed in Poa.

The accuracy and correct interpretation of these flow cytometry results were tested with six $P$. pratensis accessions previously screened by Wieners et al. (2006) (Table 1). Flow cytometry results from five of these accessions matched those previously recorded. Results from the sixth P. pratensis accession (PI 578828) indicated obligate apomixis in our data, which differed only slightly from the previous report as a facultative apomict.

\section{Ploidy Levels}

Ploidy levels ranged from $2 n=2 x=14$ to $2 n=12 x=84$ among sexually reproducing Poa accessions, and from $2 n=3 x=21$ to $2 n=10 x=70$ among apomict accessions. The median ploidy level of both apomictic and sexually reproducing accessions was $6 x$. The average ploidy level for an apomict (including facultative) among the collection was approximately $6.2 x$ (range $3 x-11 x$ ), while the average ploidy level among the sexually producing individuals was approximately $6.1 x$ (range $2 x-12 x$ ). Most apomictic accessions (including facultative accessions) had calculated ploidy levels between $2 n=4 x=28$ and $2 n=10 x=70$, while the sexually reproducing accessions had the highest occurrence of individuals between $2 n=3 x=21$ to $2 n=8 x=56$.
Accessions with missing ploidy results (including PI 229466, PI 410322, PI 232352, PI 383733, and PI 206722) were due to insufficient growth of the seedlings, or flow cytometry results were not conclusive and therefore not reported. Several $P$. pratensis accessions (PI 206725, PI 2151276, PI 226667, PI 286210, PI 440603, and PI 578828) were not analyzed, but results were previously published by Wieners et al. (2006).

Our data provide a closer look at possible ploidy levels for almost 20 Poa species that currently do not have published ploidy level information. Published data was available for 15 of the 33 Poa species in this collection and 12 specific PI accessions (Table 1). The specific accessions proved useful as an additional check for ploidy level accuracy in our work. Nine of the 12 accessions in common between our work and that of Patterson et al. (2005) matched in terms of ploidy levels, or were very close, as in several aneuploidy cases (PI 578851 and PI 325462). Several factors may have led to the discrepancies between previous ploidy level results and the Poa PIs within this collection. Although flow cytometry is a dependable and a commonly used research tool in plant genetics research, cytology and chromosome counts are still the most accurate method to make definitive conclusions. A source of potential error in ploidy analysis was the DAPI stain, which can only compare relative DNA amounts. However, the DAPI stain was satisfactory for our objectives of identifying ploidy levels rather than absolute DNA content.

If genome size varies among Poa species, the relative comparison to $P$. апnи a may have also led to errors in ploidy estimation. Variation and evolution in genome size throughout Poaceae is known to occur (Caetano-Anolles, 2005). Greater emittance in the flow cytometer, resulting in higher DNA content measurement, may be due partially to larger chromosomes rather than more chromosomes. For example, a diploid with several larger chromosomes may shift the intensity peaks on the histogram to the right enough that, when compared to $P$. апnиa, it would appear triploid. Our data indicated two $P$. trivialis as triploid (PI 227858, PI 227672), but unfortunately, these accessions were not confirmed with chromosome counts. Only PI 204484 was confirmed as a diploid (Patterson et al. (2005). However, this accession did have a higher DNA content than most diploids (Table 1).

Poa annua was chosen as a standard on the basis of availability, relatively low ploidy level $(4 x)$, was from the same genus, and because it has been used as a standard in previous ploidy level research (Johnson et al., 2001). As a result, 9 of 12 accessions agreed with previous reports, suggesting that this method was adequate for the wide 
Table 1. Reproductive modes (Repr. mode) and ploidy levels for Poa accessions, number of tests on each accession ( $n$ ), and reports on each entry or species as reported in published literature. Results in the published literature that are underlined are specific for the PI accession. Other reports from the published literature are results for the species but not for the specific accession.

\begin{tabular}{|c|c|c|c|c|c|c|c|c|c|}
\hline \multirow[b]{2}{*}{ Accession } & \multirow[b]{2}{*}{ Species } & \multicolumn{3}{|c|}{ Reproduction results } & \multirow[b]{2}{*}{$n$} & \multicolumn{2}{|c|}{ Ploidy results } & \multicolumn{2}{|c|}{ Published literature $^{\dagger}$} \\
\hline & & $n$ & $\begin{array}{c}C \\
\text { values }\end{array}$ & $\begin{array}{l}\text { Repr. } \\
\text { mode }\end{array}$ & & $\begin{array}{l}\text { Avg. peak } \\
\text { ratios }\end{array}$ & $\begin{array}{l}\text { Estimated } \\
\text { ploidy }\end{array}$ & $\begin{array}{l}\text { Repr. } \\
\text { mode }\end{array}$ & Ploidy \\
\hline PI 372559 & P. alpina & 2 & $2+5$ & apomictic & - & - & - & apomixis present (6) & \\
\hline PI 236900 & P. annua & 3 & $2+3$ & sexual & 2 & 1 & $4 x$ & no apomixis reported (5) & $\underline{4 x}(1)$ \\
\hline PI 632591 & P. arachnifera & 3 & $2+3$ & sexual & 3 & 2.97 & $12 x$ & $\begin{array}{l}\text { no apomixis } \\
\text { reported (4) }\end{array}$ & $8 x(7)$ \\
\hline PI 632539 & P. arachnifera & 2 & $2+3$ & sexual & $\begin{array}{l}2 \\
1\end{array}$ & $\begin{array}{l}2.95 \\
2.08\end{array}$ & $\begin{array}{l}12 x \\
8 x\end{array}$ & & \\
\hline PI 632500 & P. arachnifera & 3 & $2+3$ & sexual & 2 & 2.48 & $10 x$ & & \\
\hline PI 578806 & P. arida & 4 & $2+3$ & sexual & 3 & 1.5 & $6 x$ & apomixis present (9) & $\underline{9 x}(1)$ \\
\hline PI 598545 & P. attenuata & 3 & $2+5$ & apomictic & 3 & 1 & $4 x$ & & $3 x(8)$ \\
\hline PI 229466 & P. bactriana & 4 & $2+4$ & apomictic & - & - & - & & \\
\hline PI 410322 & P. binata & 2 & $2+3+5$ & facultative & - & - & - & & \\
\hline PI 314304 & P. bulbosa & 2 & $2+4$ & apomictic & - & - & - & apomixis present (10) & $\begin{array}{c}\underline{5 x}(1) \\
10 x-14 x(7)\end{array}$ \\
\hline PI 206741 & P. bulbosa & 2 & $2+4$ & apomictic & - & - & - & & $\underline{4 x}(1)$ \\
\hline PI 249766 & P. chaixii & 3 & $2+5$ & apomictic & 4 & 1.94 & $8 x$ & & \\
\hline PI 251161 & P. compressa & 3 & $2+3$ & sexual & 3 & 1.43 & $6 x$ & & \\
\hline \multirow{2}{*}{ PI 206736} & P. compressa & 3 & $2+3$ & sexual & 1 & 2.01 & $8 x$ & & $6 x-7 x(7)$ \\
\hline & & 1 & $2+3+5$ & facultative & 1 & 2.5 & $10 x$ & & \\
\hline PI 204487 & P. compressa & - & - & - & 1 & 1.55 & $6 x$ & apomixis present & \\
\hline PI 204486 & P. compressa & 3 & $2+5$ & apomictic & 1 & 1 & $4 x$ & & \\
\hline \multirow[t]{2}{*}{ PI 204485} & P. compressa & - & - & - & 1 & 2.55 & $10 x$ & & \\
\hline & & & & & 2 & 1.68 & $6 x$ & & \\
\hline \multirow[t]{2}{*}{ PI 202458} & P. compressa & 1 & $2+3+5$ & facultative & 3 & 1.53 & $6 x$ & & \\
\hline & & 1 & $2+5$ & apomictic & & & & & \\
\hline PI 182794 & P. compressa & 3 & $2+5$ & apomictic & - & - & - & & \\
\hline PI 182792 & P. compressa & 3 & $2+5$ & apomictic & - & - & - & & \\
\hline PI 243216 & P. compressa & 3 & $2+5$ & apomictic & - & - & & & $\underline{7 x}(1)$ \\
\hline \multirow[t]{2}{*}{ PI 380984} & P. densa & 2 & $2+3+5$ & apomictic & 3 & 2.25 & $9 x$ & & \\
\hline & & & & & 1 & 2.48 & $10 x$ & & \\
\hline PI 206722 & P. diversifolia & 2 & $2+3$ & sexual & 3 & 0.77 & $3 x$ & & \\
\hline PI 206729 & P. diversifolia & - & - & - & 3 & 0.76 & $3 x$ & & \\
\hline PI 204263 & P. erinacea & 3 & $2+5$ & apomictic & 3 & 1 & $4 x$ & & \\
\hline PI 383733 & P. glauca & 4 & $2+5$ & apomictic & - & - & - & apomixis present (11) & \\
\hline \multirow[t]{2}{*}{ PI 380990} & P. glauca & 2 & $2+5$ & apomictic & 1 & 1.98 & $8 x$ & & \\
\hline & & & & & 1 & 2.28 & $8 x-9 x$ & & \\
\hline PI 325462 & P. iberica & 2 & $2+3$ & sexual & 3 & 1.27 & $5 x$ & & $\underline{4 x}(1)$ \\
\hline PI 236909 & P. interior & 3 & $2+5$ & apomictic & 4 & 1.64 & $6 x-7 x$ & & $4 x(7)$ \\
\hline PI 284254 & P. iridifolia & 3 & $2+3$ & sexual & - & - & - & & $\underline{4 x}(1)$ \\
\hline \multirow[t]{2}{*}{ PI 202203} & P. lanuginosa & 3 & $2+3$ & sexual & 3 & 1 & $4 x$ & & \\
\hline & & & & & 1 & 2.1 & & & \\
\hline \multirow[t]{2}{*}{ PI 202200} & P. lanuginosa & 3 & $2+3$ & sexual & 2 & 2.5 & $10 x$ & & \\
\hline & & & & & 2 & 2.27 & $9 x$ & & \\
\hline PI 517033 & P. lingulata & 2 & $2+3$ & sexual & 2 & 2 & $8 x$ & & $\underline{2 x}(1)$ \\
\hline PI 371759 & P. nemoralis & 2 & $2+5$ & apomictic & - & - & - & & $\underline{4 x}(1)$ \\
\hline PI 251207 & P. nemoralis & 2 & $2+5$ & apomictic & 3 & 1 & $4 x$ & & \\
\hline \multirow[t]{2}{*}{ PI 206728} & P. nemoralis & 2 & $2+3+5$ & facultative & 3 & 1.46 & $6 x$ & apomixis present (5) & \\
\hline & & 1 & $2+5+6$ & apomictic & & & & & \\
\hline PI 206726 & P. nemoralis & 3 & $2+5$ & apomictic & 3 & 1 & $4 x$ & & \\
\hline PI 206680 & P. nemoralis & 3 & $2+5$ & apomictic & 3 & 1.36 & $5 x-6 x$ & & \\
\hline PI 182858 & P. nemoralis & 3 & $2+5$ & apomictic & 2 & 1 & $4 x$ & & \\
\hline \multirow[t]{2}{*}{ PI 284840} & P. nemoralis & 3 & $2+5$ & apomictic & 2 & 1.27 & $5 x$ & & \\
\hline & & & & & 1 & 1.02 & $4 x$ & & \\
\hline PI 232352 & P. nervosa & 4 & $2+4$ & apomictic & - & - & - & no sexuals reported (12) & $\underline{4 x}(1)$ \\
\hline PI 232349 & P. nervosa & 3 & $2+5$ & apomictic & 2 & 2.08 & $8 x$ & & $8 \times(7)$ \\
\hline PI 168621 & P. ochroleuca & - & - & - & 3 & 1.43 & $6 x$ & & \\
\hline
\end{tabular}


Table 1. Continued.

\begin{tabular}{|c|c|c|c|c|c|c|c|c|c|}
\hline \multirow[b]{2}{*}{ Accession } & \multirow[b]{2}{*}{ Species } & \multicolumn{3}{|c|}{ Reproduction results } & \multirow[b]{2}{*}{$n$} & \multicolumn{2}{|c|}{ Ploidy results } & \multicolumn{2}{|c|}{ Published literature $^{\dagger}$} \\
\hline & & $n$ & $\begin{array}{c}\mathrm{C} \\
\text { values }\end{array}$ & $\begin{array}{l}\text { Repr. } \\
\text { mode }\end{array}$ & & $\begin{array}{l}\text { Avg. peak } \\
\text { ratios }\end{array}$ & $\begin{array}{l}\text { Estimated } \\
\text { ploidy }\end{array}$ & $\begin{array}{l}\text { Repr. } \\
\text { mode }\end{array}$ & Ploidy \\
\hline \multirow[t]{2}{*}{ PI 255477} & P. palustris & 2 & $2+5$ & apomictic & 2 & 1 & $4 x$ & & \\
\hline & & & & & 1 & 2.5 & $10 x$ & & \\
\hline \multirow[t]{2}{*}{ PI 255476} & P. palustris & 2 & $2+3+5$ & facultative & 2 & 2.53 & $10 x$ & ne covualc ronorted & \\
\hline & & 1 & $2+5$ & apomictic & 1 & 2.72 & & no sexuals reported & \\
\hline \multirow[t]{2}{*}{ PI 369296} & P. palustris & 3 & $2+5$ & apomictic & 2 & 1 & $4 x$ & apomict (2) & \\
\hline & & & & & 1 & 2.45 & $10 x$ & & \\
\hline PI 632576 & P. palustris & 2 & $2+3+5$ & facultative & 2 & 1 & $4 x$ & & \\
\hline PI 232351 & P. palustris & - & - & - & 3 & 1 & $4 x$ & & $\underline{4 x}(1)$ \\
\hline \multirow[t]{2}{*}{ W6 19573} & P. palustris & - & - & - & 2 & 0.73 & $3 x$ & & \\
\hline & & & & & 1 & 0.67 & & & \\
\hline PI 206725 & P. pratensis & 3 & $2+3+5$ & facultative & - & - & - & $\underline{2+3+5}(2)$ & \\
\hline PI 440603 & P. pratensis & 2 & $2+5$ & apomictic & - & - & - & $2+5(2)$ & $7 x-12 x(7)$ \\
\hline PI 578828 & P. pratensis & 3 & $2+5$ & apomictic & - & - & - & $\underline{2+3+5}(2)$ & \\
\hline PI 226667 & P. pratensis & 4 & $2+3+5$ & facultative & - & - & - & $\underline{2+3+5}(2)$ & \\
\hline \multirow[t]{2}{*}{ PI 251276} & P. pratensis & 2 & $2+3+5$ & facultative & - & - & - & $\underline{2+3+5}(2)$ & \\
\hline & & 1 & $2+5$ & apomictic & & & & & \\
\hline \multirow[t]{2}{*}{ PI 286210} & P. pratensis & 2 & $2+3+5$ & facultative & - & - & - & $\underline{2+3+5}(2)$ & \\
\hline & & 1 & $2+5$ & apomictic & & & & & \\
\hline PI 298096 & P. pratensis & 2 & $2+3$ & sexual & - & - & - & $\underline{2+3}(2)$ & \\
\hline W6 23481 & P. psilolepis & 2 & $2+5$ & apomictic & 3 & 1 & $4 x$ & & \\
\hline PI 241067 & P. secunda & 3 & $2+5$ & apomictic & 2 & 2.89 & $10 x-11 x$ & & $8 x-14 x$ \\
\hline PI 232350 & P. secunda & 3 & $2+3$ & sexual & 3 & 1.47 & $6 x$ & & \\
\hline \multirow[t]{2}{*}{ PI 232347} & P. secunda & 2 & $1+3$ & apomictic & 2 & 2.57 & $10 x$ & & $10 x-12 x(7)$ \\
\hline & & & & & 1 & 2.84 & $10 x-11 x$ & apomixis present (3) & \\
\hline PI 232346 & P. secunda & 4 & $2+5$ & apomictic & 3 & 2.14 & $8 x$ & & \\
\hline PI 578851 & P. secunda & 2 & $2+5$ & apomictic & 1 & 2.5 & $10 x$ & & $\underline{9 x}(1)$ \\
\hline PI 504370 & P. secunda & 3 & $1+3$ & apomictic & 1 & 2.68 & $10 x-11 x$ & & $\underline{8 x-14 x}(1)$ \\
\hline PI 369300 & P. sibirica & 3 & $2+3+5$ & facultative & 3 & 2.02 & $8 x$ & & \\
\hline PI 240482 & P. sieberiana & 2 & $2+3$ & sexual & 1 & 1.98 & $8 x$ & & \\
\hline PI 240478 & P. sieberiana & 3 & $2+3$ & sexual & 3 & 2.06 & $8 x$ & & \\
\hline PI 209102 & P. sieberiana & 3 & $2+3$ & sexual & - & - & - & & \\
\hline PI 223403 & P. sinaica & 2 & $2+3$ & sexual & 2 & 1 & $4 x$ & & \\
\hline PI 212323 & P. sinaica & 2 & $2+3$ & sexual & 3 & 1 & $4 x$ & & \\
\hline PI 230131 & P. sterilis & 4 & $2+5$ & apomictic & 2 & 1.56 & $6 x$ & & \\
\hline PI 229962 & P. sterilis & 3 & $2+5$ & apomictic & 2 & 1.61 & $6 x$ & & \\
\hline PI 229961 & P. sterilis & 4 & $2+5$ & apomictic & 2 & 2.44 & $10 x$ & & \\
\hline PI 223403 & P. sinaica & 2 & $2+3$ & sexual & 2 & 1 & $4 x$ & & \\
\hline PI 212323 & P. sinaica & 2 & $2+3$ & sexual & 3 & 1 & $4 x$ & & \\
\hline PI 230131 & P. sterilis & 4 & $2+5$ & apomictic & 2 & 1.56 & $6 x$ & & \\
\hline PI 229962 & P. sterilis & 3 & $2+5$ & apomictic & 2 & 1.61 & $6 x$ & & \\
\hline PI 229961 & P. sterilis & 4 & $2+5$ & apomictic & 2 & 2.44 & $10 x$ & & \\
\hline \multirow[t]{2}{*}{ PI 227513} & P. sterilis & 2 & $2+5$ & apomictic & 2 & 0.75 & $3 x$ & & \\
\hline & & 1 & $2+3+5$ & facultative & & & & & \\
\hline PI 221950 & P. sterilis & 2 & $2+5$ & apomictic & 2 & 1 & $4 x$ & & \\
\hline PI 219938 & P. sterilis & - & - & - & 3 & 1 & $4 x$ & & \\
\hline PI 206732 & P. sterilis & 3 & $2+5$ & apomictic & 2 & 2.01 & $8 x$ & & \\
\hline \multirow[t]{2}{*}{ PI 610895} & P. subfastigiata & 2 & $2+3$ & sexual & 1 & 0.52 & $2 x$ & & \\
\hline & & & & & 2 & 0.72 & $3 x$ & & \\
\hline PI 227858 & P. trivialis & 2 & $2+3$ & sexual & 2 & 0.71 & $3 x$ & & \\
\hline PI 227672 & P. trivialis & 3 & $2+3$ & sexual & 3 & 0.72 & $3 x$ & no apomicts reported & \\
\hline PI 204484 & P. trivialis & 2 & $2+3$ & sexual & 3 & 0.58 & $2 x$ & & $\underline{2 x}(1)$ \\
\hline PI 206730 & P. versicolor & 3 & $2+5$ & apomictic & 2 & 0.74 & $3 x$ & & \\
\hline PI 229714 & P. versicolor & 2 & $2+5$ & apomictic & 2 & 1 & $4 x$ & & \\
\hline PI 220819 & P. versicolor & 2 & $2+5$ & apomictic & 3 & 0.65 & $3 x$ & & \\
\hline
\end{tabular}

†Numbers in parentheses refer to the following: 1 = Patterson et al. (2005); 2 = Wieners et al. (2006); 3 = Kellogg (1987); 4 = Soreng (2000); 5 = Naumova et al. (1999); 6 = Bjørnstad et al. (1995); 7 = Hartung (1946); 8 = Nie et al. (2005); 9 = Conner (1979); 10 = Stebbins (1949); 11 = Clausen (1961); 12 = Grun (1955). 
range of species. It is also possible that some discrepancies with previous reports may be due to misidentified accessions in NPGS. Several accessions originally obtained for this work were determined to be misidentified based on growth habit and were removed from the study.

Further variation would be expected among ploidy results due to the relatively few number of accessions from any given species tested in this study. The published data for species with varying ploidy levels may be appropriate and relative for only that specific Poa accession tested. Interestingly, chromosome counts were done previously on both $P$. bulbosa accessions in this collection (Patterson et al., 2005). One accession was previously determined as $5 x$ while the other was $4 x$ (Table 1). However those results were not similar to the documented ploidy levels for the species $(10 x-14 x)$ reported by Hartung (1946), who also used chromosome counts. Unfortunately, we were not able to germinate and grow a large number of $P$. bulbosa accessions in this experiment to a size needed for ploidy analysis; those that were germinated gave poor and unconsistent flow cytometry results and therefore were not reported. A similar discrepancy was also found for P. nervosa, further exemplifying the complex genomes and complex taxonomy of Poa.

\section{CONCLUSIONS}

This study has described the variability in reproductive modes and ploidy levels within Poa species. In addition, chromosome counts and ploidy level determinations are often accession specific due to the complex taxonomy and genetics of Poa. Because of the highly interspecific nature of the genus, it is likely that many Poa species are not confined to the reproduction methods presently reported in the literature. Many of the Poa species have little recorded information available, and the likelihood of collecting a new genotype within the species seems almost expected. Environmental control has also been argued to play a significant role in reproduction mode; therefore, location of origin may alter apomixis frequencies (Knox, 1967; Bashaw, 1980; Asker and Jerling, 1992; Mogie, 1992; Weddin and Huff, 1996). The reproductive modes and ploidy level results reported here are highly significant. Many of these species or accessions have never been analyzed for these traits and will offer new direction for plant breeders as well as plant taxonomists and ecologists.

\section{Acknowledgments}

We wish to especially thank Carolyn Jaussi for chromosome counts and John Carman for assistance and comments. This research was made possible by the National Turfgrass Research Initiative through the USDA-ARS Forage and Range Research Laboratory and the Utah Agricultural Experiment Station. Joint contribution of the USDA-ARS, Utah State University, and the Utah Agricultural Experiment Station. UAES Journal Paper No. 8019.

\section{References}

Abraham, E.M., B. Huang, S.A. Bonos, and W.A. Meyer. 2004. Evaluation of drought resistance for Texas bluegrass, Kentucky bluegrass, and their hybrids. Crop Sci. 44:1746-1753.

Arumuganathan, K., and E.D. Earle. 1991. Estimation of nuclear DNA contents of plants by flow cytometry. Plant Mol. Biol. Rep. 9:229-241.

Asker, S.E., and L. Jerling. 1992. Apomixis in plants. CRC Press, Boca Raton, FL.

Balasko, J.A., G.W. Evers, and R.W. Duell. 1995. Bluegrasses, ryegrasses, and bentgrasses. p. 357-371. In R.F Barnes, D.A. Miller, C.J. Nelson, M. Collins, and K.J. Moore (eds.) Forages. Vol. 1. An introduction to grassland agriculture forages. Iowa State Univ. Press, Ames.

Bashaw, E. 1980. Hybridization of crop plants. ASA and CSSA, Madison, WI.

Bashaw, E., and C. Funk. 1987. Principles of cultivar development. Vol. 2. Crop species. Macmillan, New York.

Bjørnstad, O.N., A. Iversen, and M. Hansen. 1995. The spatial structure of the gene pool of a viviparous population of Poa alpina: environmental controls and spatial constraints. Nordic J. Bot. 15:347-354.

Caetano-Anolles, G. 2005. Evolution of genome size in the grasses. Crop Sci. 45:1809-1816.

Clausen, J. 1961. Introgression facilitated by apomixis in polyploid Poa. Euphytica 10:87-93.

Conner, H.E. 1979. Breeding systems in the grasses: A survey. N.Z. J. Bot. 17:547-574

Doležel, J., and J. Bartoš. 2005. Plant DNA flow cytometry and estimation of nuclear genome size. Ann. Bot. (Lond.) 95:99-110.

Gillespie, L.J., and R.J. Soreng. 2005. A phylogenetic analysis of the bluegrass genus Poa based on cpDNA restriction site data. Syst. Bot. 30:84-105.

Grun, P. 1955. Cytogenetic Studies in Poa: III. Variation within Poa nervosa, an obligate apomict. Am. J. Bot. 42:778-784.

Hartung, M.E. 1946. Chromosome numbers in Poa, Agropyron, and Elymus. Am. J. Bot. 33:516-531.

Hovin, A. 1980. Hybridization of crop plants. ASA and CSSA, Madison, WI.

Huff, D. 2003. Kentucky bluegrass. In Turfgrass biology, genetics, and breeding. Wiley \& Sons, Hoboken, NJ.

Johnson, P.G., K.E. Kenworthy, D.L. Auld, and T.P. Riordan. 2001. Distribution of buffalograss polyploid variation in the southern Great Plains. Crop Sci. 41:909-913.

Kellogg, E.A. 1987. Apomixis in the Poa secunda complex. Am. J. Bot. 74:1431-1437.

Knox, R. 1967. Apomixis: Seasonal and population differences in a grass. Science 157:325-326 (New Series).

Matzk, F., A. Meister, and I. Schubert. 2000. An efficient screen for reproductive pathways using mature seeds in monocots and dicots. Plant J. 21:97-108.

Mogie, M. 1992. The evolution of asexual reproduction in plants. Chapman and Hall, London.

Naumova, T., J.O.V. Sharma, P. Dijkhuis, and K. Ramulu. 1999. Apomixis in plants: Structural and functional aspects of diplospory in Poa nemoralis and P. palustris. Protoplasma 208:186-195.

Nie, Z.L., J. Wen, Z.J. Gu, D.E. Boufford, and H. Sun. 2005. Polyploidy in the flora of the Hengduan mountains hotspot, southwestern China. Ann. Mis. Bot. Garden 92:275-306. 
Patterson, J.T., S.R. Larson, and P.G. Johnson. 2005. Genome relationships in polyploid Poa pratensis and other Poa species inferred from phylogenetic analysis of nuclear and chloroplast DNA sequences. Genome 48:76-87.

Soreng, R.J. 2000. Apomixis and amphimixis comparative biogeography: A study in Poa (Poaceae). In S.W.L. Jacobs and J. Everett (ed.) Grasses: Systematics and evolution. CSIRO Publishing, Collingwood, Victoria.

Stebbins, G.L. 1949. Asexual reproduction in relation to plant evolution. Evolution Int. J. Org. Evolution 3:98-101.
USDA-NRCS. 2008. National Plant Germplasm System. Available at http://www.ars-grin.gov/npgs/ (verified 11 May 2009). USDA-NRCS, Washington, DC.

Weddin, W., and D.R. Huff. 1996. Bluegrasses. In L.E. Moser et al. (ed.) Cool-season forage grasses. ASA, CSSA, and SSSA, Madison, WI.

Wieners, R.R., S. Fei, and R.C. Johnson. 2006. Characterization of a USDA Kentucky bluegrass (Poa pratensis L.) core collection for reproductive mode and DNA content by flow cytometry. Gen. Res. Crop Evol. 53:1531-1541. 